\title{
Comment on Wahl et al.: A global representation of vitamin D status in healthy populations
}

\author{
Hussein Saadi
}

Received: 30 October 2012 / Accepted: 18 January 2013 / Published online: 1 February 2013

(C) International Osteoporosis Foundation and National Osteoporosis Foundation 2013

\section{Dear Editor,}

With great interest, I read the paper by Wahl et al. [1]. I was surprised, however, that the color code in the map on vitamin D status in adults is yellow (25OHD 50-74 nmol/L) for Saudi Arabia. We [2] and others [3, 4] have shown that moderately severe vitamin D deficiency is highly prevalent in many countries of the Arabian Peninsula, including Saudi Arabia.

It is important to highlight that the reference quoted for Saudi Arabia [5] refers to a study on reference intervals of biochemical bone turnover markers. In that study, the authors excluded women whose serum 25OHD levels were $<50 \mathrm{nmol} / \mathrm{L}$. Please refer to page 805 of that publication, where under study design the authors wrote "Women who are... vitamin D-deficient with serum 25-hydroxy-vitamin D (25(OH)D) levels being $<50 \mathrm{nmol} / \mathrm{L}$ were also excluded." In fact, in another publication by the same group [6], mean (SD) 25OHD level in 1,172 Saudi Arabian women (age 50.9 \pm 12.6 years; range $20-79$ years) was $35.8 \pm 26.9 \mathrm{nmol} / \mathrm{L}$. In the 501 premenopausal women (age $39.7 \pm 7.8$ years), $25 \mathrm{OHD}$ was $43.0 \pm 30.5 \mathrm{nmol} / \mathrm{L}$, and in the 671 postmenopausal women (age $58.7 \pm 7.5$ years), $25 \mathrm{OHD}$ was $33.3 \pm 24.9 \mathrm{nmol} / \mathrm{L}$. The same group has also published their data on Saudi Arabian men

This comment refers to the article available at doi:10.1007/s11657-013$0122-7$.

\section{H. Saadi $(\bowtie)$}

Department of Medical Subspecialties, Cleveland Clinic

Abu Dhabi, Baniyas Tower B, 11W; Al Najda Street,

P O Box 112412, Abu Dhabi, United Arab Emirates

e-mail: saadih@clevelandclinicabudhabi.ae
[7], where $25 \mathrm{OHD}$ level in 834 men (age $42.1 \pm 13.9$ years; range 20-74 years) was $29.0 \pm 16.1 \mathrm{nmol} / \mathrm{L}$.

I propose that the levels published in the latter two papers be used for Saudi Arabia in the revised version of the map, thus changing the color code from yellow to orange (25OHD 25-49 $\mathrm{nmol} / \mathrm{L})$ !

\section{References}

1. Wahl DA et al (2012) A global representation of vitamin D status in healthy populations. Arch Osteoporos 7(1-2):155-172. doi:10.1007/ s11657-012-0093-0

2. Saadi HF et al (2006) Predictors and relationships of serum 25 hydroxyvitamin D concentration with bone turnover markers, bone mineral density, and vitamin D receptor genotype in Emirati women. Bone 39:1136-1143

3. Ghannam NN, Hammami MM, Bakheet SM, Khan BA (1999) Bone mineral density of the spine and femur in healthy Saudi females: relation to vitamin D status, pregnancy, and lactation. Calcif Tissue Int 65:23-28

4. El-Sonbaty MR, Abdul-Ghaffar NU (1996) Vitamin D deficiency in veiled Kuwaiti women. Eur J Clin Nutr 50:315-318

5. Ardawi MS, Maimani AA, Bahksh TA, Rouzi AA, Qari MH, Raddadi RM (2010) Reference intervals of biochemical bone turnover markers for Saudi Arabian women: a cross-sectional study. Bone 47:804-814

6. Ardawi M-SM, Qari MH, Rouzi AA, Maimani AA, Raddadi RM (2011) Vitamin D status in relation to obesity, bone mineral density, bone turnover markers and vitamin D receptor genotypes in healthy Saudi pre- and postmenopausal women. Osteoporos Int 22:463-475

7. Ardawi M-SM, Sibiany AM, Bakhsh TM, Qari MH, Maimani AA (2012) High prevalence of vitamin D deficiency among healthy Saudi Arabian men: relationship to bone mineral density, parathyroid hormone, bone turnover markers, and lifestyle factors. Osteoporos Int 23:675-686 